\title{
Mefenpyr-diethyl as a safener for haloxyfop-methyl in bahiagrass
}

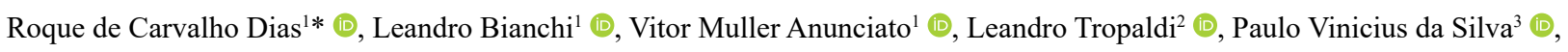

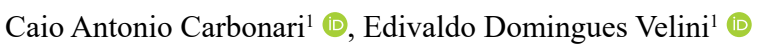 \\ ${ }^{1}$ Universidade Estadual Paulista "Júlio de Mesquita Filho", Faculdade de Ciências Agronômicas, Departamento de Proteção Vegetal, Botucatu - SP, Brazil. \\ ${ }^{2}$ Universidade Estadual Paulista "Júlio de Mesquita Filho", Faculdade de Ciências Agrárias e Tecnológicas, Departamento de Produção Vegetal, \\ Dracena - SP, Brazil. \\ ${ }^{3}$ Universidade Federal de Grande Dourados, Faculdade de Ciências Agrárias Dourados, Dourados - MS, Brazil.
}

\begin{abstract}
Mefenpyr-diethyl is a foliar-acting safener of the pyrazoline chemical group, and after its absorption, the metabolization and detoxification of herbicides occur in treated plants. Studies have demonstrated the protective effect of this safener for the herbicide fenoxaprop-P-ethyl in grass. Thus, this work aimed to evaluate whether a tank mixture of mefenpyr-diethyl has a protective response to haloxyfop-methyl in non-perennial bahiagrass. The experiment had a completely randomized design and was carried out in a greenhouse, using five replications with a 10x2 factorial scheme and ten doses of haloxyfop-methyl $(0.00,0.24,0.49,0.97$, $1.95,3.90,7.79,15.59,31.28$, and $62.35 \mathrm{~g}$ a.i. $\left.\mathrm{ha}^{-1}\right)$ in the presence or absence of a tank mixture of mefenpyr-diethyl $\left(50 \mathrm{~g}\right.$ a.i. ha $\left.\mathrm{g}^{-1}\right)$. Phytotoxicity and electron transport rate (ETR) were evaluated at 7, 14, 21, and 28 days after application (DAA), in addition to plant height and dry biomass at 28 DAA. In general, phytotoxicity increased due to the higher levels of the herbicide haloxyfopmethyl. The application of mefenpyr-diethyl, in turn, provided lower levels of phytotoxicity, as well as lower reductions in ETR, height, and dry biomass when compared to untreated plants. These results show the safener action of a tank mixture of mefenpyrdiethyl on low doses of haloxyfop-methyl in non-perennial bahiagrass.
\end{abstract}

Keywords: ACCase inhibitors; chemical protector; herbicide; Paspalum notatum.

\section{Resumo}

Mefenpyr-diethyl como safener para o uso de haloxyfop-methyl em grama batatais

O mefenpyr-diethyl é um safener de ação foliar do grupo químico das pyrazolines e após a sua absorção, ocorre à metabolização e desintoxicação de herbicidas em plantas tratadas. Estudos demonstraram efeito protetor desse safener para o herbicida fenoxaprop-Pethyl em gramíneas. Assim, o objetivo desse trabalho foi avaliar se o mefenpyr-diethyl em mistura de tanque possui resposta protetora ao haloxyfop-methyl em grama batatais não perenizada. $\mathrm{O}$ experimento foi realizado em casa de vegetação em delineamento inteiramente casualizado, com cinco repetições com esquema fatorial 10x2, sendo dez doses do haloxyfop-methyl $(0.00 ; 0,24 ; 0,49 ; 0,97 ; 1,95 ; 3,90$; 7,$79 ; 15,59 ; 31,28 \mathrm{e} 62,35 \mathrm{~g} \mathrm{ha}^{-1}$ i.a.), na presença ou ausência do mefenpyr-diethyl ( $50 \mathrm{~g} \mathrm{ga}^{-1}$ i.a. $)$ em mistura de tanque. Foram realizadas avaliações de fitointoxicação e taxa de transporte de elétrons (ETR) aos 7, 14, 21 e 28 dias após a aplicação (DAA), além de altura e biomassa seca da parte aérea das plantas aos 28 DAA. De maneira geral, houve aumento da fitointoxicação das plantas em função do aumento do herbicida haloxyfop-methyl. A aplicação de mefenpyr-diethyl por sua vez, proporcionou menores níveis de fitointoxicação, menores reduções de ETR, altura e biomassa seca quando comparadas as plantas não tratadas. Estes resultados mostram a ação protetora de mefenpyr-diethyl em mistura em tanque com baixas doses de haloxyfop-methyl em grama batatais não perenizada.

Palavras-chave: inibidores da ACCase; protetor químico; herbicida; Paspalum notatum.

\section{Introduction}

Native to the American continent, the species popularly known as bahiagrass (Paspalum notatum Flügge) is a creeping, low-growing, perennial plant that forms a dense cover over the soil. Also, it is very persistent, reproduces through seeds, and multiplies from rhizomes (Steiner et al., 2017). It presents high rusticity, increased resistance to drought and acidic soils, and low fertility. Therefore, it is mainly used as lawn in low-maintenance areas, such as the

*Corresponding author: roquediasagro@gmail.com 
sides of highways and industrial areas, in addition to its great importance as forage (Marchi et al., 2016; Souza et al., 2016; Souza et al., 2020). However, bahiagrass grows excessively during Spring and Summer due to heavy rains and high temperatures, thus requiring continuous maintenance, mainly regarding pruning (Lima et al., 2020).

Furthermore, weeds may interfere in several ways in the formation of turfgrass/pastures, impairing their conduction as they compete for water, light, nutrients, and physical space; in many cases, they can cause the death of the plant. Besides, weed-free residential or commercial lawns increase the value of the property and the attractiveness of the business (Brighenti et al., 2019). The use of herbicides can be a rapid, effective option, with little dependence on labor, to avoid or minimize the negative effects of weeds. Nonetheless, the effectiveness of herbicides relies on different variables, such as herbicide selectivity, which in some cases can be achieved using safeners or chemical protectors, allowing the increase in crop selectivity and enabling different alternatives for chemical weed control (Hatzios and Burgos, 2004; Busi et al., 2017).

Safeners are substances that have been used to protect cultivated species from the action of other substances such as herbicides, therefore avoiding harm in the emergence, growth, and development of treated plants (Duhoux et al., 2017). According to these authors, the protective action of safeners may be related to several factors, including the increase in enzyme/protein activity, enzyme inhibition, or metabolization of active compounds. Its high botanical specificity can activate specific enzymes, such as cytochrome monooxygenase (P450), glutathione $S$-transferase (GST), or glycosyltransferases (GT), which may result in crop selectivity (Nandula et al., 2019).

Haloxyfop-methyl is a systemic herbicide of the aryloxyphenoxypropionic (APP) chemical group, which inhibits the enzyme acetyl coenzyme-A carboxylase (ACCase), responsible for catalyzing the synthesis reactions of fatty acids by interrupting the formation of lipids and cell membranes (Sasanfar et al., 2017). In Brazil, it is registered for post-emergence grass control in soybean, cotton, and beans (Brasil, 2020). Thus, studies on selectivity using herbicides, such as haloxyfop-methyl, that control weeds morphologically similar to the target plant become an important tool for the chemical management of these species.

The protective action of the mefenpyr-diethyl safener for the herbicides fenoxaprop-P-ethyl and iodosulfuronmethyl has been reported, resulting in significant improvements in the safety of its application in crops, such as white oats, wheat, rye, triticale, and barley (Hacker et al., 2000; Queiroz et al., 2017). In addition, according to Bianchi et al. (2020), the use of mefenpyr-diethyl can stimulate action in wheat and soybean plants.

Thus, this work aimed to evaluate the effects of applying a tank mixture of mefenpyr-diethyl as a safener for haloxyfop-methyl in non-perennial bahiagrass.

\section{Material and Methods}

The experiments were conducted in a greenhouse maintained at a temperature of $27 \pm 2^{\circ} \mathrm{C}$ under natural sunlight. The experimental units consisted of 1.7-L pots filled with a commercial substrate with the following physical/chemical properties: sphagnum peat, vermiculite, roasted expanded rice husk, dolomite (limestone), plaster, and NPK traits; electric conductivity $(E C)=0.7 \mathrm{mS}$ ${ }^{1} \pm 0.3 \mathrm{~cm} ; \mathrm{pH}=5.5$; density $=155 \mathrm{~kg} \mathrm{~m}^{-3}$; water holding capacity $=55 \%$.

Bahiagrass seeds were sown at a depth of 1-2 cm, and after emergence, thinning was carried out, maintaining two plants per experimental unit. During the conduction of the experiment, the pots were irrigated whenever necessary in order to maintain the humidity required for the development of the plants. The experiment was performed in a randomized complete block design, using five replications with a 10x2 factorial scheme and ten doses of the herbicide in the presence or absence of a spray mixture of mefenpyrdiethyl (50 g a.i. "active ingredient" $\mathrm{ha}^{-1}$ ).

At 30 days after emergence, when the plants were $15 \mathrm{~cm}$ tall, haloxyfop-methyl was applied at doses of $0,0.24,0.49,0.97$, $1.95,3.90,7.79,15.59,31.28$, and $62.35 \mathrm{~g}$ a.i. ha ${ }^{-1}$, with $0.5 \%$ $(\mathrm{v} / \mathrm{v})$ of adjuvant. The sprayer was equipped with a $2.0 \mathrm{~m}$ spray bar and four XR 110.02 VS nozzles spaced $0.5 \mathrm{~m}$ apart. The spray bar was positioned $0.5 \mathrm{~m}$ above the plants and operated at a speed of $3.6 \mathrm{~km} \mathrm{~h}^{-1}$. It applied a volume corresponding to $200 \mathrm{~L}$ $\mathrm{ha}^{-1}$ under the constant pressure of $150 \mathrm{kPa}$ by compressed air. At the time of application, temperature and relative air humidity were $24^{\circ} \mathrm{C}$ and $74 \%$, respectively.

Phytotoxicity level, height, electron transport rate (ETR) of FSII, and dry weight of plants were evaluated at 7, 14, 21, and 28 days after application (DAA). ]Phytotoxicity was determined using a scale with grades ranging from 0 to 100 ; " 0 " indicated the complete absence of injury, and "100" indicated the complete death of the plant (SBCPD, 1995). ETR was calculated with a portable modulated fluorometer, using the Yield protocol of the Multi-Mode Chlorophyll Fluorometer OS5p (Opti-Science). The readings were done with the leaves completely open and photosynthetically active. Plant height $(\mathrm{cm})$ and dry weight were measured at $28 \mathrm{DAA}$. The plants were weighed on a precision scale $(0.0001 \mathrm{~g})$, stored in paper bags, and dried in a forced-air circulation oven at $60^{\circ} \mathrm{C}$ until constant weight.

The results obtained were subjected to analysis of variance by the F test. When the F test was significant, the results were adjusted for non-linear log-logistic regression models (dose-response curve methodology), proposed by Streibig (1988) (Equation 1):

$y=\frac{a}{\left[1+\left(\frac{x}{b}\right)^{c}\right]}$

In which:

$\mathrm{y}=$ percentage of phytotoxicity, ETR, plant height, and dry weight;

$\mathrm{x}=$ herbicide dose $\left(\mathrm{g}\right.$ a.i. $\left.\mathrm{ha}^{-1}\right)$;

$\mathrm{a}=$ asymptote between the maximum and minimum values of the variable;

$\mathrm{b}=$ dose that provides $50 \%$ of the response variable;

$\mathrm{c}=$ slope of the curve. 


\section{Results and Discussion}

Symptoms of haloxyfop-methyl phytotoxicity were observed from 7 DAA onward, regardless of the application of mefenpyr-diethyl (Figure 1) in P. notatum plants. Of note, the plants originated from young and nonperennialized seeds. These symptoms, characterized by the yellowing of leaves and chlorosis, followed by necrosis, increased with the doses and over the evaluated periods. After its absorption, haloxyfop-methyl is translocated to the growth points through the phloem, so the meristem growth in the aerial part and the root is interrupted. The occurrence of the aforementioned symptoms is related to the disintegration of these meristematic regions, leading to newly formed leaves having such characteristics (Takano et al., 2021).

The analysis of the effect of mefenpyr-diethyl showed lower values of phytotoxicity regardless of the periods of evaluation (Figure 1), demonstrating the protective effect of this molecule. The greatest reductions in the presence of mefenpyr-diethyl were 45 and $16 \%$, respectively, at 7 and 14 DAA for $62.35 \mathrm{~g}$ a.i. ha $^{-1}$ of the herbicide, $26 \%$ at 21 DAA when using $15.59 \mathrm{~g}$ a.i. ha ${ }^{-1}$, and $30 \%$ at 28 DAA in $7.79 \mathrm{~g}$ a.i. ha ${ }^{-1}$.

Concerning ETR, similarly to phytotoxicity, the application of haloxyfop-methyl on $P$. notatum reduced this variable as the doses were incremented (Figure 2). Chlorophyll fluorescence analysis is based on the fact that the light energy absorbed by the chlorophyll is used to conduct photosynthesis, and this excess of energy is released as heat and fluorescence (Recchia et al., 2017). Thus, the negative influence on this parameter may be related to the negative interference in the functionality of the photosynthetic apparatus or to the effects of exogenous stresses (Hassannejad et al., 2020), such as the inhibition of lipid and cell membrane synthesis through the action
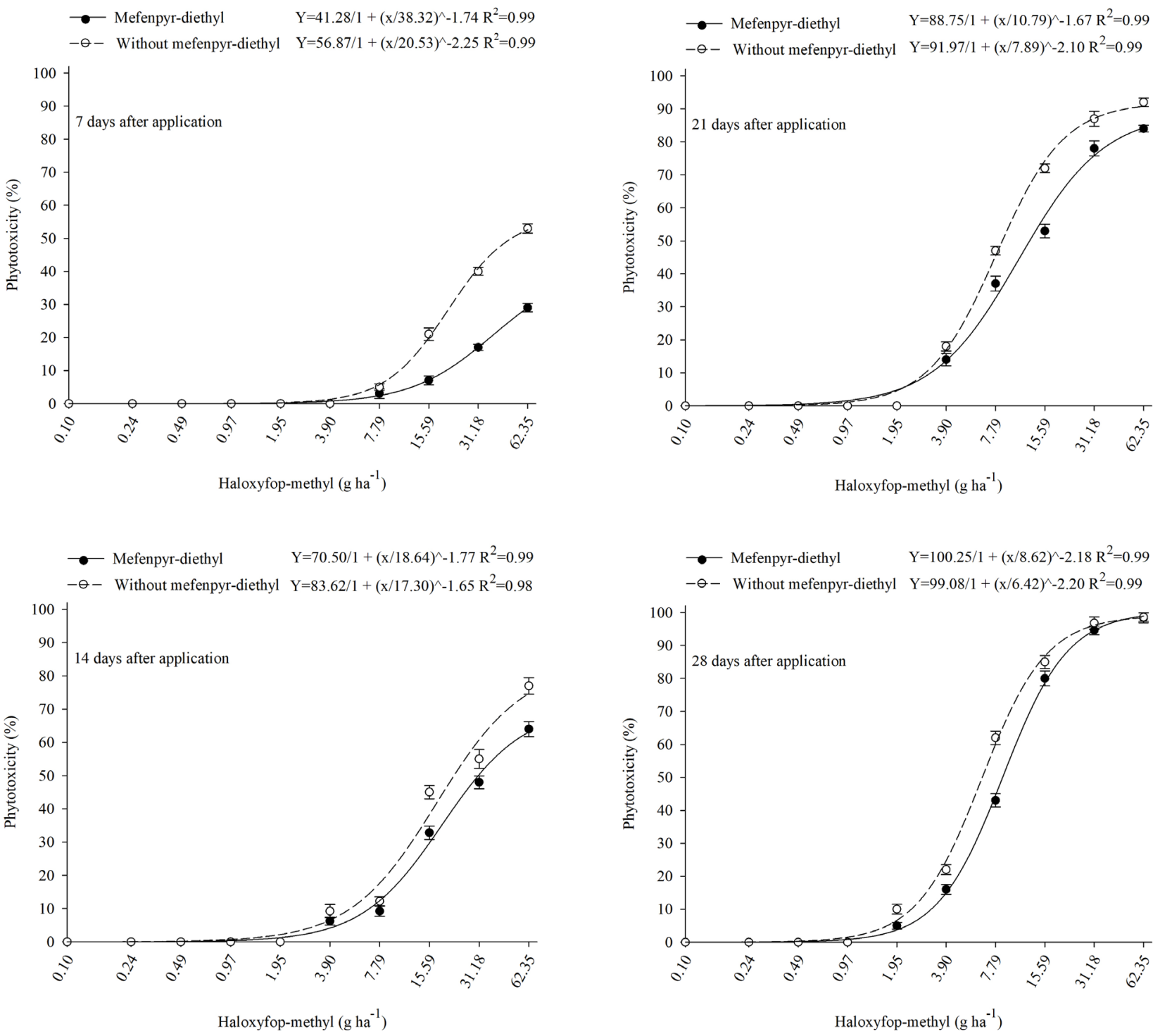

Figura 1. Phytointoxication (\%) on $P$. notatum plants as a function of haloxyfop-methyl $\left(\mathrm{g} \mathrm{ha}^{-1}\right.$ a.i.) doses with and without the application of mefenpyr-diethyl at 7, 14, 21 and 28 days after application. Vertical bars represent standard error of mean $(n=5)$. 
of herbicides, reducing the ETR. These data corroborate those of Araldi et al. (2011), who found a reduction in ETR in brachiaria grass after haloxyfop-methyl application. According to these authors, the use of chlorophyll fluorescence analysis allows the rapid identification of injuries to the photosynthetic apparatus caused by herbicides, even when the symptom is not yet visible, until a detailed analysis of the alteration in the photosynthetic capacity of the plant is performed.

With respect to ETR, as in the evaluation of phytotoxicity, the use of mefenpyr-diethyl helped minimize the deleterious effects of the haloxyfop-methyl herbicide in the treated plants (Figure 2). In general, these effects were concentrated in the intermediate doses of this study, from 1.95 to $15.59 \mathrm{~g}$ a.i. $\mathrm{ha}^{-1}$ of haloxyfop-methyl. The literature has no studies reporting the positive influence of using mefenpyr-diethyl based on ETR; thus, we highlight the importance of the results obtained in this work to promote the understanding of these involved physiological processes.

When $P$. notatum plants received the haloxyfop-methyl application, their height and dry biomass decreased with the increment of doses, regardless of the application of a tank mixture of mefenpyr-diethyl (Figure 3). However, the effects were reduced in doses between 1.95 and 15.59 $\mathrm{g}$ a.i. ha $\mathrm{h}^{-1}$ of haloxyfop-methyl when the plants were treated with mefenpyr-diethyl. For height and biomass, the greatest protective effect was, respectively, 31 and $36 \%$ in the $7.79 \mathrm{~g}$ a.i. ha ${ }^{-1}$ dose for $P$. notatum plants treated with mefenpyr-diethyl, which is in agreement with the protective effect also found in the other variables analyzed.

The protective activity of mefenpyr-diethyl against herbicides with the same mechanism of action of haloxyfopmethyl is common for cereals, such as wheat, barley, or oats. The use of mefenpyr-diethyl can attenuate the phytotoxic
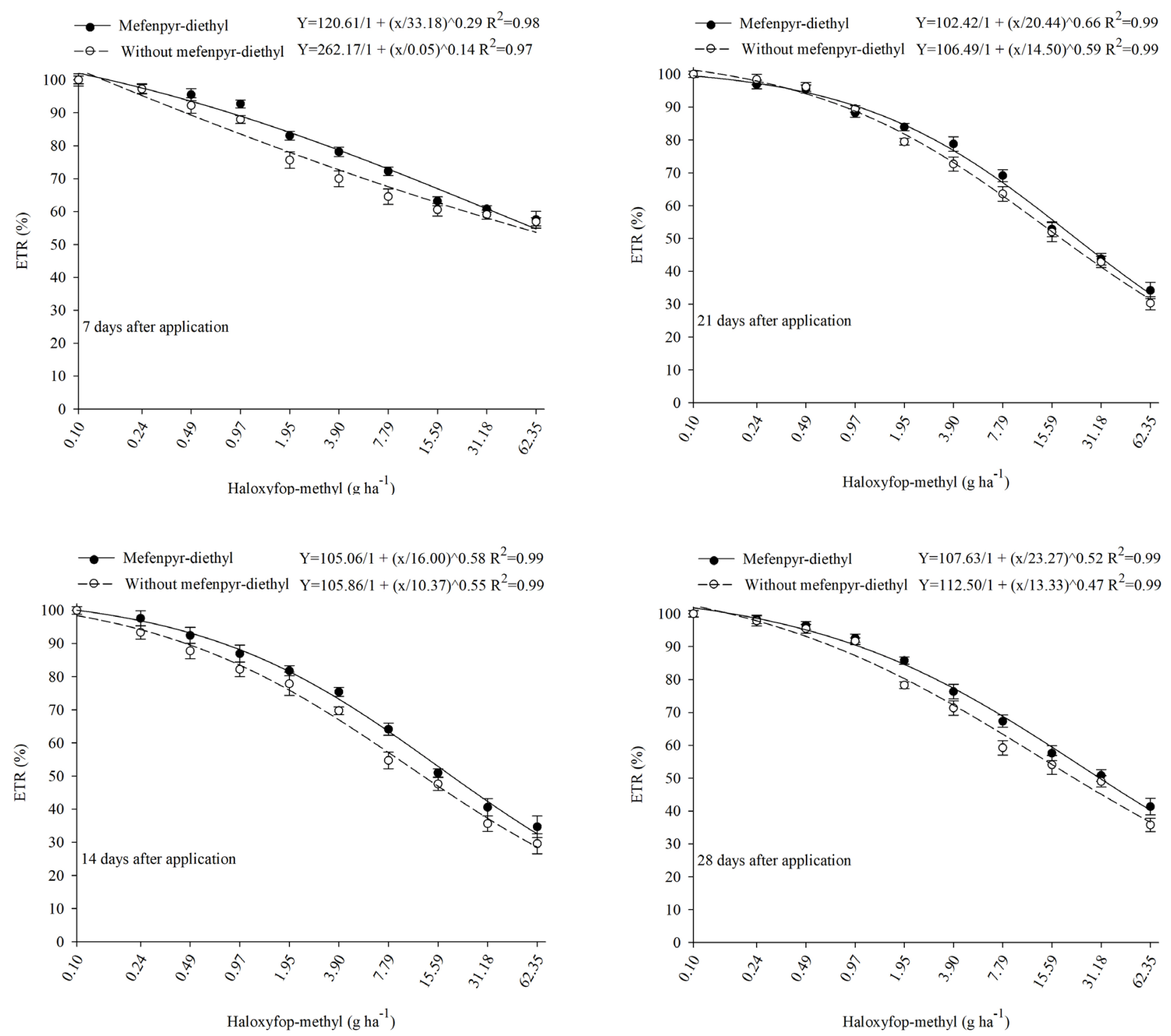

Figura 2. Electron transfer rate (ETR) (\%) on $P$. notatum plants as a function of haloxyfop-methyl (g ha ${ }^{-1}$ a.i.) doses with and without the application of mefenpyr-diethyl at 7, 14, 21 and 28 days after application. Vertical bars represent standard error of mean $(n=5)$. 


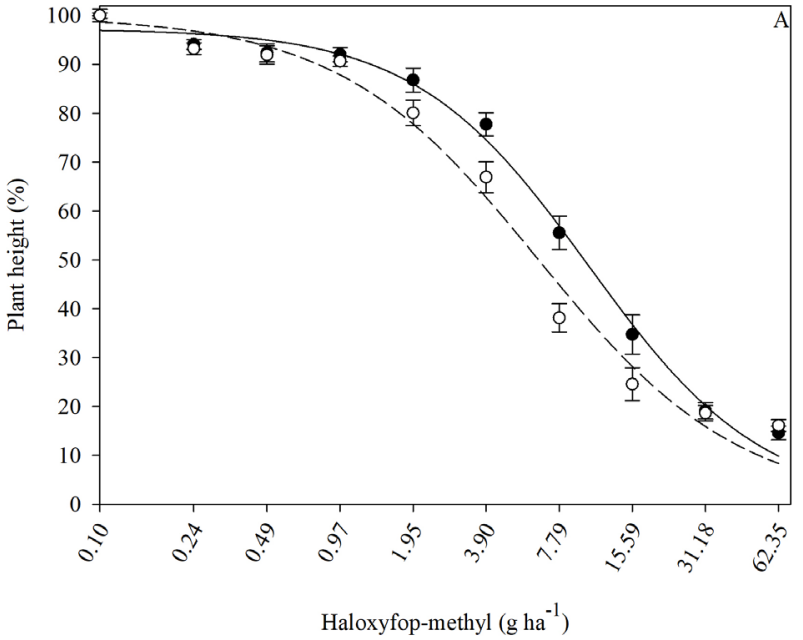

- Mefenpyr-diethyl $\quad \mathrm{Y}=97.31 / 1+(\mathrm{x} / 10.35)^{\wedge} 1.20 \mathrm{R}^{2}=0.98$ $-\ominus-$ Without mefenpyr-diethyl $Y=99.88 / 1+(\mathrm{x} / 6.43)^{\wedge} 1.05 \mathrm{R}^{2}=0.98$

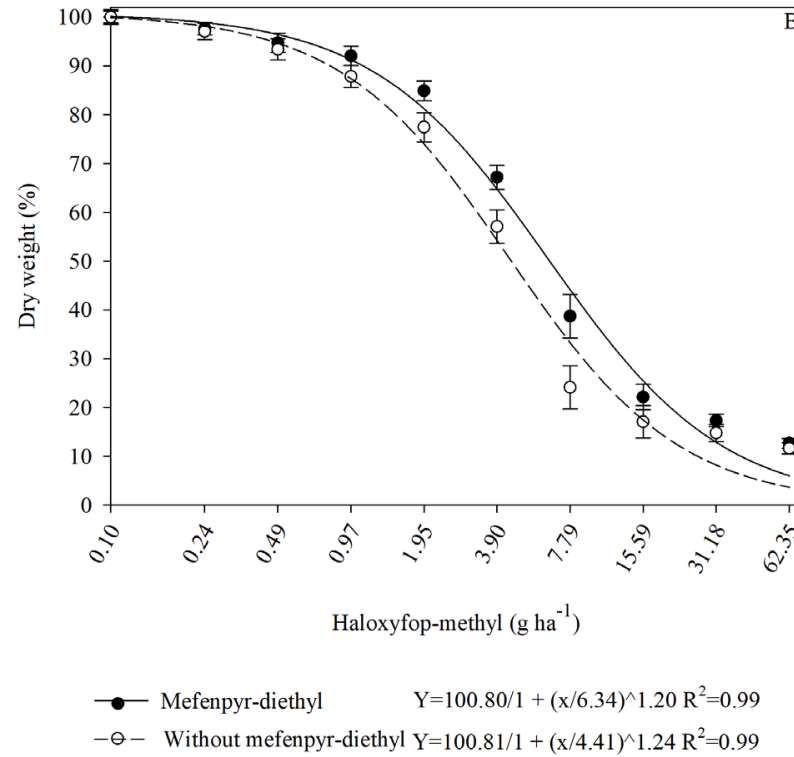

Figura 3. Plant height (\%) (A) and dry weight (\%) (B) on P. notatum plants as a function of doses of haloxyfopmethyl ( $\mathrm{g} \mathrm{ha}^{-1}$ a.i.) with and without the application of mefenpyr-diethyl at 28 days after application. Vertical bars represent standard error of mean $(n=5)$.

effects of fenoxaprop-P-ethyl (Hacker et al., 2000; Cataneo et al., 2013). This attenuation is related to the action of specific enzymes on these crops. In general, the action of safeners may be related to the induction of the expression of antioxidant enzymes, such as GST, GT, and P450, in metabolizing herbicides (Duhoux et al., 2017). Studies on wheat and barley have shown that mefenpyr-diethyl had higher GST accumulations (Scalla and Roulet, 2002; Cummins et al., 2009; Taylor et al., 2013), a result strongly related to the protective action of this molecule. Bartucca et al. (2017) found an increase in the enzymatic activity of ATP sulfurylase in barley, which, according to these authors, is responsible for minimizing abiotic stresses in plants.

Thus, the protective effect of mefenpyr-diethyl on plants that received this treatment is evident; however, it is not as intense at the highest doses of the herbicide. We emphasize that several factors may be involved in the maximization of the effects of safeners, for example, dose, growth stage of the plant, environmental conditions, absorption and translocation, distribution of antioxidant enzymes, among others (Bianchi et al., 2020). Taylor et al. (2013) revealed that, for safeners including mefenpyrdiethyl, the effect on wheat varied based on the plant stage and that the accumulation of GST classes was different in the analyzed plant parts.

In short, we found evidence that the use of mefenpyrdiethyl, as well as other safeners, minimizes the effects of herbicides, indicating a promising strand of studies; nevertheless, little information is available on the functioning of the physiological and molecular mechanism of such effect. Further studies on these effects and the specification of the correct use regarding dose, phenological stage, and target species should contribute to expanding the use of safeners.

\section{Conclusions}

The results found in the present study indicate positive effects of the use of mefenpyr-diethyl as a safener. The application of a tank mixture of mefenpyr-diethyl ( $50 \mathrm{~g}$ a.i. $\mathrm{ha}^{-1}$ ) resulted in the protection of non-perennial bahiagrass against low doses of haloxyfop-methyl.

\section{Acknowledgments}

This study was partly funded by the Coordenação de Aperfeiçoamento de Pessoal de Nível Superior (CAPES) Finance Code 001. We also thank to the Conselho Nacional de Desenvolvimento Científico e Tecnológico (CNPq) for their financial support for the research throughout the project (Process No. 140683/2018-6).

\section{Author Contribution}

RCD: Investigation, methodology, writing, original draft. LB: Formal analysis, methodology, writing, original draft. VMA: Investigation, writing, original draft. LT: Visualization, writing, original draft, writing, review and editing. PVS: Writing, original draft, writing, review and editing. CAC: Project administration, resources, writing, review and editing. EDV: Project administration, resources, writing, review and editing.

\section{References}

ARALDI, R.; VELINI, E.D.; GIROTTO, M.; CARBONARI, C.A.; JASPER, S.P.; TRINDADE, M.L.B. Efeitos na taxa de transporte de elétrons de plantas daninhas após aplicação de amicarbazone. Planta Daninha, v.29, n.3, p.647-653, 2011. https://doi.org/10.1590/S0100-83582011000300019 
BARTUCCA, M.L.; CELlETTI, S.; ASTOLFI, S.; MIMMO, T.; CESCO, S.; PANFILI, I.; DEL BUONO, D. Effect of three safeners on sulfur assimilation and iron deficiency response in barley (Hordeum vulgare) plants. Pest Management Science, v.73, n.1, p.240-245, 2017. https://doi.org/10.1002/ps.4291

BIANCHI, L.; PERISSATO, S.M.; ANUNCIATO, V.M.; DIAS, R.C.; GOMES, D.M.; CARBONARI, C.A.; VELINI, E.D. Stimulation action of mefenpyr-diethyl on soybean, wheat, and signal grass plants. Journal of Environmental Science and Health, Part B, v.56, n.2, p.163-167, 2020. https://doi.org/10.1080/03601234.2020. 1853459

BRASIL. Ministério da Agricultura, Pecuária e Abastecimento. AGROFIT - Sistema de Agrotóxicos Fitossanitários. Available in <http://agrofit.agricultura. gov.br/agrofit_cons/principal_agrofit_cons $>$ Accessed on: Oct 3, 2020.

BRIGHENTI, A.M.; BENITES, F.R.G.; SOUZA SOBRINHO, F. African star grass response to postemergence herbicides. Ciência e Agrotecnologia, v.43, n.e026918, 2019. https://doi.org/10.1590/14137054201943026918

BUSI, R.; NGUYEN, N.K.; CHAUHAN, B.S.; VIDOTTO, F.; TABACCHI, M.; POWLES, S.B. Can herbicide safeners allow selective control of weedy rice infesting rice crops? Pest Management Science, v.73, n.1. p.71-77, 2017. https://doi.org/10.1002/ps.4411

CATANEO, A.C.; FERREIRA, L.C.; MISCHAN, M.M.; VELINI, E.D.; CORNIANI, N.; CERDEIRA, A.L. Mefenpyr-diethyl action on fenoxaprop-p-ethyl detoxification in wheat varieties. Planta Daninha, v.31, n.2, p.387-393, 2013. https://doi.org/10.1590/S010083582013000200016

CUMMINS, I.; BRYANT, D.N.; EDWARDS, R. Safener responsiveness and multiple herbicide resistance in the weed black-grass (Alopecurus myosuroides). Plant Biotechnology Journal, v.7, n.8, p.807-820, 2009. https:// doi.org/10.1111/j.1467-7652.2009.00445.x

DUHOUX, A.; PERNIN, F.; DESSERRE, D.; DÉLYE, C. Herbicide safeners decrease sensitivity to herbicides inhibiting acetolactate-synthase and likely activate nontarget-site-based resistance pathways in the major grass weed Lolium sp. (Rye-grass). Frontiers in Plant Science, v.8, p.1-14, 2017. https://doi.org/10.3389/fpls.2017.01310

HACKER, E.; BIERINGER, H.; WILLMS, L.; RÖSCH, W.; KÖCHER, H.; WOLF, R. Mefenpyr-diethyl: a "safener" for fenoxaprop-P-ethyl and iodosulfuron in cereals. Journal of Plant Diseases and Protection, v.17, p.493-500, 2000.
HASSANNEJAD, S.; LOTFI, R.; GHAFARBI, S.P.; OUKARROUM, A.; ABBASI, A.; KALAJI, H.M.; RASTOGI, A. Early identification of herbicide modes of action by the use of chlorophyll fluorescence measurements. Plants, v.9, n.4, p.529, 2020. https://doi.org/10.3390/ plants 9040529

HATZIOS, K.K.; BURGOS, N. Metabolism-based herbicide resistance: regulation by safeners. Weed Science, v.52, n.3, p.454-467, 2004. https://doi.org/10.1614/P2002$168 \mathrm{C}$

LIMA, B.H.; SANTOS, P.L.F.; BEZERRA, J.C.M.; PAGLIARINI, M.K.; CASTILHO, R.M.M. Paclobutrazol as growth regulator in Bahiagrass. Ornamental Horticulture, v.26, n.3, p.413-421, 2020. https://doi. org/10.1590/2447-536x.v26i3.2205

MARCHI, S.R.; MARTINS, D.; COSTA, N.V. Growth and flowering inhibition of Paspalum notatum with application of trinexapac-ethyl and prohexadione-calcium. Revista Brasileira de Engenharia Agrícola e Ambiental, v.20, n.3, p.202-208, 2016. https://doi.org/10.1590/1807-1929/ agriambi.v20n3p202-208

NANDULA, V.K.; RIECHERS, D.E.; FERHATOGLU, Y.; BARRETT, M.; DUKE, S.O.; DAYAN, F.E.; GOLDBERGCAVALLERI, A.; TÉTARD-JONES, C.; WORTLEY, D.J.; ONKOKESUNG, N.; BRAZIER-HICKS, M.; EDWARDS, R.; GAINES, T.; IWAKAMI, S.; JUGULAM, M.; MA, R. Herbicide metabolism: crop selectivity, bioactivation, weed resistance, and regulation. Weed Science, v.67, n.2, p.149-175, 2019. https://doi.org/10.1017/wsc.2018.88

QUEIROZ, A.; VIDAL, R.; NAVA, I.; PACHECO, M.; FEDERIZZI, L.; XAVIER, E. Selectivity of iodosulfuron-methyl to oat cultivars. Planta Daninha, v.35, n.e017165822, 2017. https://doi.org/10.1590/s010083582017350100022

RECCHIA, I.; SPARLA, F.; PUPILLO, P. Photosynthetic properties of spring geophytes assessed by chlorophyll fluorescence analysis. Plant Physiology and Biochemistry, v.118, p.510-518, 2017. https://doi.org/10.1016/j. plaphy.2017.07.020

SASANFAR, H.; ZAND, E.; BAGHESTANI, M.A.; MIRHADI, M.J.; MESGARAN, M.B. Cross-resistance patterns of winter wild oat (Avena ludoviciana) populations to ACCase inhibitor herbicides. Phytoparasitica, v.45, n.3, p.419-428, 2017. https://doi.org/10.1007/s12600-0170587-9

SCALLA, R.; ROULET, A. Cloning and characterization of a glutathione S-transferase induced by a herbicide safener in barley (Hordeum vulgare). Physiologia Plantarum, v.116, n.3, p.336-344, 2002. https://doi.org/10.1034/j.13993054.2002.1160308.x 
SOCIEDADE BRASILEIRA DA CIÊNCIA DAS PLANTAS DANINHAS (SBCPD). Procedimentos para instalação, avaliação e análise de experimentos com herbicidas. Londrina: SBCPD, 1995. 42p.

SOUZA, F.H.D.; GUSMÃO, M.R.; MATTA, F.P.; CASTRO, A.C.R.; MITTELMANN, A.; FÁVARO, A.P.; JANK L. Atributos desejáveis para gramados a serem cultivados sob condições brasileiras: uma proposta. Ornamental Horticulture, v.22, n.2, p.154-165, 2016. https://doi.org/10.14295/oh.v22i2.841

SOUZA, F.H.D.; GUSMÃO, M.R.; CAVALLARI, M.M.; JR., W.B. Characterization of the potential of native grasses for use as lawns. Ornamental Horticulture, v.26, n.1, p.109-120, 2020. https://doi.org/10.1590/2447-536X. v26i1.2067

STEINER, M.G.; DALL'AGNOL, M.; NABINGER, C.; SCHEFFER-BASSO, S.M.; WEILER, R.M.; SIMIONI, C.;
SCHIFINO-WITTMANN, M.T.; MOTTA, E.A.M. Forage potential of native ecotypes of Paspalum notatumand $P$. guenoarum. Anais da Academia Brasileira de Ciências, v.89, n.3, p.1753-1760, 2017. https://doi.org/10.1590/00013765201720160662

STREIBIG, J.C. Herbicide bioassay. Weed Research, v.28, n.3, p.479-484, 1988.

TAKANO, H.K.; OVEJERO, R.F.L.; BELCHIOR, G.G.; MAYMONE, G.P.L.; DAYAN, F.E. ACCase-inhibiting herbicides: mechanism of action, resistance evolution and stewardship. Scientia Agricola, v.78, n.1, e20190102, 2021. https://doi.org/10.1590/1678-992X-2019-0102

TAYLOR, V.L.; CUMMINS, I.; BRAZIER-HICKS, M.; EDWARDS, R. Protective responses induced by herbicide safeners in wheat. Environmental and Experimental Botany, v.88, p.93-99, 2013. https://doi.org/10.1016/j. envexpbot.2011.12.030 